\title{
Proč moje děti nechodí do mateřské školy. Přístup rodičů, jejichž rozhodování neomezuje socioekonomické znevýhodnění 1
}

\author{
Helena Picková \\ Technická univerzita v Liberci, Fakulta prrírodovědně-humanitní a pedagogická, \\ Katedra pedagogiky a psychologie \\ Univerzita Karlova, Pedagogická fakulta, Ústav výzkumu a rozvoje vzdělávání
}

\begin{abstract}
Abstrakt: Předložená studie si klade za cíl porozumět tomu, proč někteří rodiče z běžných středostavovských rodin neposílají své předškolní děti do mateřské školy nebo je tam posílají jen velmi nepravidelně. Data z hloubkových rozhovorů s matkami, která byla získána v rámci dlouhodobého sledování šesti rodin z Libereckého kraje v období předškolního ročníku a vstupu do povinného vzdělávání, byla podrobena obsahové analýze. Analýza identifikovala čtyři hlavní témata: silný ochranitelský výchovný styl rodiny; eliminace nedostatků z dětství rodičů; nedůvěra v zajištění všestranného rozvoje dítěte mateřskou školou; předčasná scholarizace. Výsledky jsou diskutovány vzhledem k uzákonění povinné docházky do předškolního ročníku mateřské školy.
\end{abstract}

Klíčová slova: preprimární vzdělávání, předškolní ročník, nízká docházka, střední třída

\section{Why My Children Do Not Attend Nursery School. Attitudes of Parents Whose Decision Making Is Not Limited by Socioeconomic Disadvantage}

Abstract: The study presented here aims to understand why some parents from ordinary middle-class families do not send their preschool children to kindergarten or send them only very irregularly. Data from in-depth interviews with mothers, which was obtained as part of the longitudinal monitoring of six families from the Liberec region during the pre-school year and commencement of compulsory education, was subjected to a content analysis. The analysis identified four main themes: a strong protective family style of education; compensating for problems experienced during the parents' own childhood; mistrust that the kindergarten will ensure the child's comprehensive development, and early scholarization. The results are discussed with regard to the enactment of compulsory attendance of the pre-school year of kindergarten.

Keywords: pre-primary education, pre-school year, low attendance, middle-class

Preprimárním (předškolním) vzděláváním rozumíme etapu vzdělávání dětí před nástupem do základní školy. Dítě získává v tomto období života především sociální zkušenosti a základní poznatky o světě kolem sebe. Tato etapa tak předurčuje do značné míry rozvoj jeho předpokladů i sociálních postojů a je klíčová pro utváření jeho osobnosti. Pro vývoj dítěte má předškolní vzdělávání velký význam, nebot' rané

1 Tento text byl připraven s podporou projektu GA ČR „,16-10057S“ financovaného Grantovou agenturou České republiky. 
52 zkušenosti dítěte, přijaté podněty a poznatky i z mimorodinného prostředí mají obvykle trvalou hodnotu a uplatní se i zhodnotí v jeho budoucím životě.

$\checkmark$ mnoha výzkumech nalézáme důkazy potvrzující význam preprimárního vzdělávání na rozvoj dítěte, z nichž vyplývá, že předškolní vzdělávání usnadňuje pozdější učení (např. Barnett, 1995; Berlinski, Galiani, \& Gertler, 2006; Schütz, 2009; Rühm \& Waldfogel, 2012). Z údajů Evropské komise pro vzdělání, výchovu, kulturu a mládež (EACEA P9 Eurydice, 2009) vyplývá, že nejefektivnější je investovat právě do počátečních forem vzdělání. Pozdější náprava nedostatků bývá už velmi neúčinná. Komise to $v$ rámci Aktualizovaného strategického rámce evropské spolupráce $v o b$ lasti vzdělávání a odborné prípravy (Komise evropských společenství, 2006) shrnuje následovně:

... Preprimární vzdělávání vykazuje největší návratnost, pokud jde o sociální adaptaci dětí. Členské země by proto měly více investovat do preprimárního vzdělávání jako efektivního prostředku, který představuje základ pro další učení, je prevencí předčasného ukončování školní docházky a zvyšuje spravedlnost výsledků a celkovou úroveň dovedností.

I z nedávného výzkumu PISA (OECD, 2014) mimo jiné vyplývá, že malé děti, které se naučily, jak se chovat ve skupinách, a byly seznámeny se základy písmen a čísel, jsou lépe připraveny pro školní docházku než děti, které tyto dovednosti a zkušenosti nemají.

Prokázaný pozitivní dopad předškolního vzdělávání na vzdělávací dráhu žáka vede $\checkmark$ posledních letech u tvůrců vzdělávacích politik ve vyspělých zemích $\mathrm{k}$ zvýšenému zájmu o tuto etapu. $V$ některých vzdělávacích systémech jsou koncipovány komplexní předškolní programy pro sociálně znevýhodněné žáky, jiné systémy zavádějí povinné předškolní vzdělávání, rostoucí důraz je kladen na ranou péči. V EU byly stanoveny společné cíle pro míru účasti dětí na preprimárním vzdělávání (Evropský parlament, 2013): u dětí ve věku od čtyř let do zahájení povinné školní docházky dosáhnout alespoň 95\% účasti na předškolním vzdělávání a péči. U mladších 3 let by mělo být dosaženo $33 \%$ účasti.

ČR se přihlásila k tomuto cíli ve Strategii vzdělávací politiky České republiky do roku 2020 (MŠMT, 2014) a stanovila, že podíl dětí ve věku od 4 let do věku obvyklého pro zahájení docházky do základní školy, který se účastní předškolního vzdělávání, by měl v roce 2020 dosáhnout hodnoty alespoň $95 \%$ (oproti 86,1\% v roce 2012). MŠMT také zavádí povinný rok předškolního vzdělávání před zahájením povinné školní docházky od školního roku 2017/2018 - viz vládou schválená novela školského zákona (zákon č. 178/2016 Sb.). Současné znění Rámcového vzdělávacího programu pro předškolní vzdělávání platného od 1. září 2016 v této souvislosti uvádí:

... Úkolem institucionálního předškolního vzdělávání je doplňovat a podporovat rodinnou výchovu a v úzké vazbě na ni pomáhat zajistit dítěti prostředí s dostatkem mnohostranných a přiměřených podnětů $\mathrm{k}$ jeho aktivnímu rozvoji a učení. Předškolní vzdělávání smysluplně obohacuje denní program dítěte $v$ průběhu jeho předškolních let a poskytuje dítěti odbornou péči. Usiluje o to, aby první vzdělávací krůčky dítěte byly stavěny 
na promyšleném, odborně podepřeném a lidsky i společensky hodnotném základě... (MŠMT, 2016)

Pozornost odborné veřejnosti $v$ souvislosti s preprimárním vzděláváním je věnována zvláště sociálně znevýhodněným dětem. Pro utváření osobnosti dítěte hraje sice nejdůležitější roli rodina, ale ne každá je schopna zajistit mnohostrannou škálu podnětů, které dítě předškolního věku potřebuje, proto brzké vzdělávání pro něj může představovat značný přínos (viz např. Yoshikawa, 1995; Melhuish, 2004; Gambaro, Stewart, \& Waldfogel, 2014). Systematický přehled poznatků o dopadech mezinárodních intervenčních programů na vzdělávací dráhu dětí ze sociálně znevýhodněného prostředí přináší kniha Spravedlivý start? (Greger, Simonová, \& Straková, 2015). Výsledky z výzkumu PISA (OECD, 2014) ukazují, že patnáctiletí žáci, kteří navštěvovali předškolní vzdělávání, mají tendenci dosahovat lepších výsledků než ti, kteří se nezúčastnili předškolního vzdělávání, a to i když je brán v úvahu jejich socioekonomický status.

Pokud by všechny děti, bez ohledu na socioekonomické postavení svých rodin, měly přistup ke kvalitním předškolním programům, mohlo by to pomoci k snižení nerovností $v$ oblasti připravenosti na školu, které jsou zapřičiněny rozdílným rodinným zázemím žáka. Výsledky výzkumu PISA (OECD, 2014) však poukazují na to, že žáci znevýhodnění svým rodinným zázemím se nejméně účastní preprimárního stupně vzdělávání. Je tedy zřejmé, že právě ti, kteří by mohli nejvíce těžit z programů předškolního vzdělávání, mají menši šanci se jich zúčastnit. Zmiňovaný rozdíl je pozorován téměř ve všech zemích, které se zúčastnily výzkumu PISA, ale mezi jednotlivými zeměmi jsou výrazné diference - viz Kleňhová (2013) a OECD (2014). ČR ve Strategii vzdělávací politiky České republiky do roku 2020 (MŠMT, 2014) proto uvádí záměr systematicky zvyšovat účast na předškolním vzdělávání dětí ze skupin a lokalit ohrožených sociálním vyloučením s cílem snižit znevýhodnění těchto žáků při vstupu do povinného vzdělávání.

Systematický přehled výzkumů provedených v oblasti předškolního vzdělávání v České republice $v$ letech 2000-2010 přináší studie Syslové a Najvarové (2012). Z této studie vyplývá, že názorům rodičủ a jejich očekáváním od předškolního vzdělávání se věnovala Šmelová (2005), ale šetření prováděla na rodinách dětí, které navštěvovaly mateřskou školu. Problematikou spravedlivosti v předškolním vzdělávání se zabývá již výše zmiňovaná kniha Spravedlivý start? (Greger et al., 2015). Kromě tam již zmiňovaných zahraničních studií, které evaluovaly předškolní programy pro znevýhodněné děti, jako je Head Start, jsou zde zevrubně citovány v tomto kontextu i domácí výzkumy. Velká pozornost je věnována docházce romských dětí a zkoumání příčin, proč do mateřské školy nechodí. Kniha také shrnuje výsledky z rozsáhlého šetření rodin $\mathrm{s}$ dětmi, které měly nastoupit v následujícím školním roce do základní školy. Toto šetření proběhlo $v$ roce 2014 na reprezentativním výběru mateřských škol a jeho cílem bylo mimo jiné zjistit, jak je volba mateřské a základní školy podmíněna rodinným zázemím, kognitivními schopnostmi dítěte a případně dalšími faktory. Provedený výzkum však nepostihuje rodiny, jejichž děti mateřskou školu nenavštěvují. 
Jak je výše uvedeno, existuje řada studií, které se zabývají rodinami s nízkým socioekonomickým statusem, jejichž děti navštěvují mateřské školy v malé míře. Málo informací však máme o běžných rodinách, které své děti do mateřské školy neposílají. Inspiraci pro výzkumy týkající se motivace těchto rodin lze nalézt ve studiích týkajících se volby péče o dítě. Earlyová a Burchinalová (2001) na datech z šetření domácností ohledně výchovy a vzdělávání provedeného v roce 1995 v USA ukazují, že typ péče o dítě, který rodiče volí, závisí na př́ijmu rodiny, etnickém původu a věku dítěte. Kim a Framová (2009) z dat podobného šetření z roku 2005 uskutečněného v USA zmiňují také etnický původ a věk a jako další faktory doplňují postavení rodičů v zaměstnání, socioekonomický status rodiny a pohlaví dítěte. Johansenová, Leibowitzová a Waiteová (1996) poukazují, že důležitým faktorem při výběru péče o dítě je v USA dosažené vzdělání matky. Téma docházky dětí do mateřských škol je široce diskutováno laickou veřejností především v USA, jak ukazují rešerše webových stránek. Příklady důvodů, proč rodiče neposílají své děti do mateřské školy, uvádí O‘Hehir (2010). V rodičovských diskusích zaznívá, že děti v mateřských školách jsou jen systematicky rozvíjeny a posléze i testovány $v$ předmatematické a čtenářské gramotnosti, ale že nemají čas si hrát, přestože výzkumy ukazují, jak je to důležité - viz Miller a Almonová (2009). Na druhé straně nalézáme i argumenty, proč je pro děti důležitá docházka do mateřské školy - viz např́klad GreatSchools (2016).

$\checkmark$ ČR je toto téma nyní relevantní vzhledem $\mathrm{k}$ uzákonění povinného předškolního ročníku, které se týká všech rodin, nejen znevýhodněných. Je tedy důležité se zabývat také komplikacemi, které bude představovat povinná docházka pro rodiny, které nyní své děti do mateřské školy posílají, ale činí tak na dobrovolné bázi. Tato práce hledá odpověd' na otázku, jaké důvody vedou rodiče, jejichž rozhodování neomezuje socioekonomické znevýhodnění, $k$ tomu, že jejich děti mateřskou školu nenavštěvují. Vhled do jejich motivace pomůže porozumět problémům, které mưže těmto rodinám přinést povinný předškolní ročník.

\section{Cíle a metodologie šetření}

Cílem našeho výzkumu bylo najít případy dětí z rodin bez socioekonomického znevýhodnění, které bud' nenavštěvují mateřskou školu, nebo ji navštěvují jen sporadicky. Dále se podrobně seznámit $s$ důvody tohoto jevu, zjistit názory rodičů dětí na výchovu a vzdělávání v předškolním období a na úlohu předškolního vzdělávání. Jako hranici „minimální docházky“ jsme si zvolili, že dítě dochází do MŠ v průměru méně než dvakrát týdně.

$Z$ údajů MŠMT lze zjistit, jaký podíl dětí nenavštěvuje mateřskou školu v jednotlivých věkových kategoriích - ve školním roce $2014 / 2015$ to bylo 9,4 \% ročníku pětiletých. Není z něho však patrné, jaké je rozložení tohoto podílu mezi dětmi sociálně znevýhodněnými a dětmi bez tohoto handicapu. $V$ souladu s cílem našeho výzkumu je nutné nejdřive alespoň rámcově ukázat, že skupina rodin bez socioekonomického znevýhodnění je početně nezanedbatelná a z hlediska výzkumu tak potenciálně 
zajímavá. Abychom si udělali základní představu o velikosti této části populace, dotázali jsme ředitelů základních škol v Libereckém kraji (prosinec 2014) na počty žáků v 1. třídách, kteří nenavštěvovali mateřskou školu. ${ }^{2}$ Spolu s tím jsme zjišt'ovali, kolik z nich může být považováno za žáky ze sociálně znevýhodněných rodin. Autorce článku je známo z dlouholeté učitelské praxe, že každý zkušený učitel v 1. třídě obvykle již během několika týdnů pozná, z jakého rodinného prostředí žák pochází. Pojem sociálně znevýhodněná rodina jsme $v$ tomto kontextu uvažovali jako rodinu, která nedostatečně podporuje své dítě ve vzdělávání, nedostatečně komunikuje se školou či se v blízkosti dítěte objevují riziková chování - rưzné druhy závislostí, násilí nebo př́padně i zneužívání.

Získali jsme údaje ze základních škol v kraji, které navštěvuje téměř 50 \% celkového počtu všech žáků v 1 . třídách. Z nich vyplývá, že 96,1 \% z těchto žáků navštěvovalo mateřskou školu. Lze konstatovat, že byly proporcionálně odpovídajícím způsobem ${ }^{3}$ zastoupeny jednotlivé typy škol včetně základních škol praktických, což je důležitý aspekt při odhadu podílu dětí s nízkým socioekonomickým statusem z těch, co nenavštěvovaly mateřskou školu. Ze zjištěných údajů vyplývá, že tento podíl činí 17,8 \% což odpovídá přibližně 1,6 \% dětí z celkového populačního ročníku. Naše zjištění poměrně dobře odpovídají odhadům, které prezentovaly společnosti Tady a ted' a Demografické informační centrum v rámci řešení projektu Kudy vede cesta, který probíhal od 1. července 2013 do 30. června 2015 a byl prováděn na území celé ČR (Hůle et al., 2015). Obecně bychom mohli konstatovat, že větší část dětí, které nenavštěvují MŠ v Libereckém kraji, nejsou děti ze sociálně znevýhodněných rodin.

Předmětem našeho výzkumu jsou děti bez socioekonomického znevýhodnění v posledním roce před nástupem do základní školy, které nenavštěvují (nebo navštěvují jen v malé míře) mateřskou školu. Provádíme-li jakékoli šetření v této populaci dětí před nástupem do školy, musíme se vyrovnat s problémem, jakým způsobem je najít a jak oslovit.

Rozhodli jsme se tyto rodiny identifikovat při zápisu do 1. třídy ve dvaceti základních školách v Libereckém kraji. Byly voleny z různých okresů a velikostí obcí, aby byla zajištěna rozmanitost prostředí, ve kterém rodiny žijí, a aby na druhé straně bylo možné oslovit všechny rodiče zapisovaných dětí s otázkou:

Jak často navštěvuje vaše dítě mateřskou školu?

(a) 4-5 dnů týdně

(b) 2-3 dny týdně

(c) $1 \times$ týdně

(d) méně často nebo velmi nepravidelně

(e) není přihlášeno do MŠ

2 E-mailem byly obeslány $v$ prosinci 2014 všechny školy Libereckého kraje, návratnost odpovědí byla zhruba $30 \%$. Opakovaně byly e-mailem v lednu 2015 kontaktovány školy, které neodpověděly. Podařilo se tak získat informace z přibližně $52 \%$ ZŠ v kraji.

3 Porovnání s populací ZŠ v Libereckém kraji ukázalo, že získaný výběr dobře reprezentuje ZŠ z pohledu regionálního, typu školy i velikosti sídla a velikosti školy. 
Pokud odpověd' rodičů byla (c), (d) nebo (e), byli přizváni k našemu výzkumu, který byl koncipován jako longitudinální kvalitativní šetření. Sedm rodin pozvání akceptovalo a podílelo se na výzkumu formou víceprípadové studie, která probíhala $\checkmark$ několika časových horizontech kvưli zachycení proměny názorů, postojů a chování rodin $v$ průběhu času a provedení komparace jednotlivých př́padů během určitého časového období. Data byla získávána prostřednictvím rozhovorů s matkami, dětmi a učitelkami, byla provedena rovněž diagnostika dítěte. $V$ této stati představujeme pouze obsahovou analýzu dat získaných z rozhovorů s matkami.

Základní charakteristiky rodin byly stanoveny na základě provedených rozhovorů. Ve většině prípadů autorka tohoto článku vstupovala opakovaně do tázaných domácností, mohla tak posoudit vybavenost domácností, oblečení, hračky apod. Z výpovědí na některé otázky $v$ rozhovoru vyplýval vztah $k$ penězům a jejich případný (ne) dostatek, vzdělání a zaměstnání rodičůu, zájmy rodiny, volnočasové aktivity a jejich finanční náročnost, možnosti trávení dovolené. Autorka má navíc dvacetiletou zkušenost s prací učitelky na 1 . stupni běžné sídlištní základní školy, do které docházely děti i ze sociálně a ekonomicky problematických rodin. Tato zkušenost posouzení statusu rodiny byla promítnuta i do rozhovorů s dětmi i jejich matkami. Vytvořený názor na charakterizaci rodiny byl pak následně ověřován ještě při rozhovoru s učitelkou dítěte po jeho nástupu do 1 . tř́ídy.

V tabulce 1 uvádíme takto získané základní charakteristiky rodin. $Z$ našeho zkoumaného vzorku se vymykala rodina č. 2 , kterou lze hodnotit jako rodinu s nízkým socioekonomickým statusem. Vzhledem $\mathrm{k}$ cíli této studie jsme ji proto do dalších analýz nezařadili.

Tabulka 1 Přehled základních charakteristik zkoumaných rodin

\begin{tabular}{|c|c|c|c|c|c|}
\hline $\begin{array}{l}\text { Rodina } \\
\text { č. }\end{array}$ & $\begin{array}{l}\text { Expertní odhad } \\
\text { socioekonomického } \\
\text { statusu }\end{array}$ & Místo bydliště & Vzdělání rodičů & $\begin{array}{l}\text { Současné } \\
\text { zaměstnání }\end{array}$ & $\begin{array}{l}\text { Počet } \\
\text { dětí }\end{array}$ \\
\hline 1 & střední & $\begin{array}{l}\text { krajské } \\
\text { město, bytový } \\
\text { dům }\end{array}$ & oba rodiče VŠ & $\begin{array}{l}\text { matka na } M D, \\
\text { otec manažer } \\
\text { zahraniční firmy }\end{array}$ & tři \\
\hline 2 & nízký & $\begin{array}{l}\text { krajské } \\
\text { město, } \\
\text { ubytovna pro } \\
\text { sociálně slabé }\end{array}$ & $\begin{array}{l}\text { oba rodiče SOŠ, } \\
\text { otec ve výkonu } \\
\text { trestu, matka žije } \\
\text { s př́telem }\end{array}$ & $\begin{array}{l}\text { matka na MD, } \\
\text { přítel dělník }\end{array}$ & tři \\
\hline 3 & vyšší & $\begin{array}{l}\text { malé horské } \\
\text { město, bytový } \\
\text { dům }\end{array}$ & $\begin{array}{l}\text { matka SOŠ, otec } \\
\text { SŠ }\end{array}$ & $\begin{array}{l}\text { matka i otec } \\
\text { provozní } \\
\text { v penzionu }\end{array}$ & dvě \\
\hline 4 & střední & $\begin{array}{l}\text { okresní } \\
\text { město, starší } \\
\text { rodinný dům }\end{array}$ & $\begin{array}{l}\text { oba rodiče } \\
\text { vŠ, matka } \\
\text { samoživitelka }\end{array}$ & $\begin{array}{l}\text { matka } \\
\text { projektantka, } \\
\text { otec učitel SŠ }\end{array}$ & dvě \\
\hline
\end{tabular}




\begin{tabular}{|c|c|c|c|c|c|}
\hline 5 & střední & $\begin{array}{l}\text { menší město, } \\
\text { rodinný dům }\end{array}$ & matka Vš, otec SŠ & $\begin{array}{l}\text { matka odborná } \\
\text { referentka MÚ, } \\
\text { otec stavební } \\
\text { dozor }\end{array}$ & dvě \\
\hline 6 & vyšší & $\begin{array}{l}\text { okresní město, } \\
\text { moderní } \\
\text { rodinný dům }\end{array}$ & $\begin{array}{l}\text { matka SŠ, otec } \\
\text { SOŠ }\end{array}$ & $\begin{array}{l}\text { matka } \\
\text { v domácnosti, } \\
\text { otec podnikatel } \\
\text { ve stavebnictví }\end{array}$ & dvě \\
\hline 7 & vyšší & $\begin{array}{l}\text { okresní město, } \\
\text { moderní } \\
\text { rodinný dům }\end{array}$ & matka VŠ, otec SŠ & $\begin{array}{l}\text { matka na MD, } \\
\text { otec podnikatel, } \\
\text { majitel fitness } \\
\text { centra }\end{array}$ & dvě \\
\hline
\end{tabular}

\section{Sběr a analýza dat}

\subsection{Vstupní rozhovor $v$ roce 2015}

S vybranými rodinami byl na jaře 2015 veden polostrukturovaný rozhovor s otevřenými otázkami. Osnova rozhovoru byla složena z vybraných základních tematických okruhů: důvody nenavštěvování mateřské školy, úloha mateřské školy v přípravě na školní vzdělávání, příprava $v$ rodině na přechod $z$ preprimárního do primárního vzdělávání a rozvoj dětí v rámci rodinných aktivit, názor rodiny na novelu školského zákona v oblasti preprimárního vzdělávání uzákonit zavedení povinného posledního roku před vstupem do základní školy, představa o další vzdělávací dráze dítěte. Byly též pokládány otázky, které směřovaly k zjištění vzdělání a zaměstnání rodičů, finanční situace rodiny, koníčků a trávení volného času včetně dovolené. Rozhovory byly nahrávány na diktafon a uskutečňovaly se obvykle $v$ domácnosti rodiny, ve dvou případech i mimo domácnost (park, kavárna). Účastnily se ho vždy matky dětí, $\checkmark$ případě rodiny č. 7 byli přítomni oba rodiče. Délka nahrávaného rozhovoru byla zhruba 30 minut, ale vlastní setkání bylo mnohem delší, protože mu předcházela fáze neformální, jejímž účelem bylo navození důvěry a vysvětlení záměru šetření. Z těchto neformálních částí setkání byly pořizovány poznámky.

Po návštěvě rodin a následné analýze rozhovorủ bylo užitečné v některých případech telefonicky či e-mailem kontaktovat opakovaně rodiny za účelem upřesnění některých dílčích nejasností. Komunikace s rodinami byla bezproblémová, umocněna nastolením vzájemné důvěry. S některými matkami byl z jejich impulzu navázán užší až přátelský vztah, rády se neformálně setkávaly za účelem popovídání si o rodině, o jejich dětech i o problémech, které rodiny trápí. Z těchto setkání jsme získali velké množství poznámek a dokreslujících informací souvisejících s postoji a názory rodin. 
Vedení rozhovorů s rodinami bylo opakované na jaře 2016 v druhém pololetí 1. třídy. Nosná témata rozhovorů zůstala shodná jako v případě vstupního rozhovoru nedlouho po zápisu. Byly zjišt’ovány podrobnosti přechodu do povinného vzdělávání, vnímané dopady nedostatečné docházky do mateřské školy, hodnocení volby základní školy. Dále jsme se tázali, zda rodina změnila pohled na zavedení povinného posledního roku v mateřské škole před vstupem do základní školy. Forma vedení rozhovoru a případný následný telefonický či e-mailový kontakt zůstaly stejné jako v roce 2015.

\subsection{Analýza dat}

Před analýzou bylo nutné získaná data zpracovat a upravit. Ze zvukových nahrávek rozhovorů byla provedena transkripce do textové podoby. Přibližně třicetiminutové rozhovory odpovídaly 10-19 normostranám textu. Pro přepis rozhovorů byla použita transkripční pravidla podle Leixové (2006). Následně byly přepisy anonymizovány, tj. všechna osobní jména a názvy, které by umožnily identifikaci rodin, byly nahrazeny smyšlenými jmény či znaky nebo byly zcela vypuštěny.

Zdrojová data (dva rozhovory) byla podrobena obsahové analýze v souladu s podobnou situací, jakou uvažuje Patton (1990) nebo Dvořák et al. (2010). V našem výzkumu to znamenalo především extrakci podobných témat spojenou s rozborem jednotlivých shod a rozdílů u jednotlivých rodin.

Konkrétně bylo postupováno následovně: 1) datové zdroje byly analyzovány individuálně; 2) data byla kódována, aby došlo k redukci dat na smysluplné celky a vytvoření širších kategorií pro prezentaci dat; 3) byly definovány nové kategorie syntetizováním a hledáním vzájemných vztahů; 4) porovnáním kategorií ze všech uvažovaných datových zdrojů byly některé kategorie zpřesněny nebo reorganizovány.

\section{Výsledky}

V našem výzkumu jsme identifikovali následující témata: (a) silný ochranitelský výchovný styl rodiny; (b) eliminace nedostatků z vlastního dětství; (c) nedůvěra v zajištění všestranného rozvoje dítěte mateřskou školou; (d) předčasná scholarizace.

\subsection{Silný ochranitelský výchovný styl rodiny}

Ze získaných dat zaznívá u všech rodin významný akcent na vnímání potřeb dítěte, který by bylo možné v řadě případů hodnotit až jako přehnaný. Rodiče dětem vycházejí vstříc ve snaze splnit jejich přání, snaží se je uchránit před nepohodlím a nepř́ijemnostmi, ulevují jim od jakýchkoli povinností. Jak ukázaly výpovědi matek, tento př́stup je s pravidelnou docházkou do mateřské školy neslučitelný. 
Matka v rodině č. 6 se snaží respektovat synova přání, když usoudí, že je jeho odůvodnění rozumné, vyhoví mu. Není pro ni problém mu vše splnit, bere to jako samožrejmost:

... když má náznak, že je nemocnej... rýmu a cokoli a někdy, když se mu třeba i nechce, že si chce odpočinout nebo že je ošklivo, že prší a že se mu nechce na procházku v pláštěnce... nebo, že se mu nechce do loutkovýho divadla... tak prostě, když nechce, tak nechce... tak jako si myslím, že není důvod, aby musel...

Dokonce i učitelka v mateřské škole, kam chlapec dochází jen občas, ji upozorňovala, že se jí zdá, že syn mưže vše, ale nesouhlasí s ní:

... takže třeba když tam zůstává na spinkání, tak třeba zapomeneme plyšáka... tak já říkám, že mu ho přinesu, a paní učitelka mi říká, nevozte ho, já mu tady pưjčím, a Mates, mami, přivez mi ho, a já ř́kám jo. Ale pro mě není problém jako se tam stavit... a paní učitelka začíná kroutit očima, že jako... [smích] no jo no.

Také staršího syna, kterému je čtrnáct roků, vozí matka každý den do školy a ze školy, snaží se mu věnovat a být k dispozici. Pokud se jde se sousedkou projít či si zaběhat, starší syn jde s nimi. Ráda mu také připravuje svačinu do školy, nechce, aby si ji někde sám kupoval. Dle ní není nutné, pokud je doma, aby se chlapci zapojovali do domácích prací a do chodu domácnosti, vše pro ně nachystá a připraví. Od mladšího syna nikdy neodchází, jednou se o to pokusila, když večer navštívila kamarádku, ovšem vrátila se předčasně, když se syn dožadoval její přítomnosti. Tento svůj přístup obhajuje i proti otci chlapců s tím, že jsou to děti a ona vnímá jako správné jim zajistit maximální péči:

... ale já si myslím, že to je chyba toho manžela, no, že by se mohl trošku... no, nevím... to už je asi zase na jiný téma... je to takový... nejsem sama bez nich a ani mi to nevadí jako... jsem ráda s nima.

Matka z rodiny č. 7 trávila dobu, kdy starší dcera byla předškolačka, na mateřské dovolené s mladší dcerou, proto využívala volnější režim a řídila se, stejně jako matka v předcházejícím případě, momentální náladou a chutí dcery:

... když jsem měla tu možnost... nebo když nám, nedej bože, nezazvonil budík, nebo když Jana ráno řekla, mně se nechce... nechci říct, že to bylo tak strašný, ale nebyla tady ta nutnost... nebyla tady ta nutnost, takže to dítě tím pádem nebylo tam dávaný.

Matka z rodiny č. 4 nechává rozhodnutí, čemu se budou věnovat a co chtějí právě dělat, na dcerách. Chápe, že činnosti, kterým se věnují, je musí zaujmout a není chyba jejich, pokud je něco nebaví, ale toho učitele či lektora, který je dostatečně nezaujme a nemotivuje:

... že tam se řekne, ted'kon se jdou hrát hry a všichni je hrajou, jo... a s tím měla Mirka na začátku velký problém, rríká, ale mami, ale mně se ta hra ale vưbec jako hrát nechce, 
tak já přece nebudu předstírat... jsem říkala, tak viš co, tak se domluvíme, tak to prostě Luňákovi, to je ten vedoucí, to je přezdívka [se smíchem]... přijdeš a řekneš.

U chlapce z rodiny č. 3 si matka prosadila odklad školní docházky, přestože u zápisu do 1. tř́dy se projevoval podle jejích slov velmi dobře a škola odklad nedoporučovala. Hlavní motivací matky bylo prodloužení bezstarostného dětství syna:

... odklad jsem mu dala hlavně kvưli tomu, že mi přišel ještě hodně dětský, že si chtěl hodně hrát, že by to pro něj bylo... asi stresující, protože je takovej... takže jsem si tak jako říkala, že mu ten rok prodloužení takovýho toho dětství jakoby.

$\checkmark$ rodině č. 1 prostřední dítě, pro které matka získala místo $v$ MŠ až v posledním roce před nástupem do základní školy kvưli přeplněnosti mateřských škol, nebylo zvyklé na kolektiv dětí a většinu roku bylo nemocné. Matka je na rodičovské dovolené a velmi se mu věnuje. Zdraví syna je pro ni velmi důležité, pokud by chodila do zaměstnání, starala by se o něj se stejnou péčí, a to i v př́padě, kdyby šlo „jen“ o rýmu.

Tazatelka: ... a nedá se nic dělat, protože maminy musej' do práce, že jo.

Matka: no tydle typy opravdu nemám ráda... protože to je... no tak ve chvíli, kdy je tam další dítě se zelenou rýmou, my ji do druhýho dne máme taky... tydle typy opravdu nemám ráda a nedávám je.

Do této kategorie jsme zařadili i situaci, kdy se rodiče snažili uchránit svého syna od domnělých negativních účinků očkování, což synovi znemožnilo docházku do běžné mateřské školy. $V$ rodině č. 5 chlapec negativně reagoval na očkování, rodiče pak odmítli podstoupit s dítětem další očkování, i když z pohledu oficiálního lékařského hlediska k obavám nebyl důvod a dítě bylo očkovatelné. Rodině to podstatně zkomplikovalo životní situaci, protože chlapce nešlo umístit do veřejné mateřské školy. Přesto rodiče neváhali a preferovali řešení, které bylo nejlepší z pohledu potřeb jejich syna.

\subsection{Eliminace nedostatků z vlastního dětství}

V prvních rozhovorech rodiče popisovali důvody, proč jejich děti nechodí do mateřské školy, ale na „prvni“ pohled nebyly mnohdy zřetelné motivy jejich jednání. Ty se začaly vyjevovat často až $v$ opakovaných rozhovorech a především při následné analýze jednotlivých souvislostí. Můžeme konstatovat, že jednání většiny dotazovaných matek je vlastně reakcí na jejich dětství, přičemž negativní zkušenosti, kterých chtějí své děti ušetřit, se $v$ jednotlivých případech liší.

Rodiče matky z rodiny č. 6 byli velmi zaměstnaní, pracovali celé dny $v$ restauraci a na ni a jejího mladšího bratra měli málo času. $V$ raném dětství trávila proto mnoho času u babiček, později se již starala jak sama o sebe, tak i o bratra. Na jedné straně výchovu rodičů vnímala jako volnou, ale naopak ji poznamenala starost o domácnost a hlavní její zátěží se stala péče o bratra, která byla zejména na ní. Především tyto 
zkušenosti přispěly k jejímu jinému přístupu ve výchově svých synů. Snaží se jim vytvořit bezproblémové zázemí, kdy potřeby a zájmy synů jsou pro ni na prvním místě. Nechce kopírovat svoje dětství a dělat stejné „chyby“ jako její rodiče. Snaží se proto být svým synům stále $\mathrm{k}$ dispozici a vytvořit jim zázemí lepší, než měla ona sama:

... nebo mi přijde zbytečný, aby starší hlídal svého bráchu... no, to už mám asi z domova, to mám asi z dětství... takže mu nedávám žádný instrukce ve stylu: ted' budeš hlídat, já jdu tamhle... ne, tak to u nás nefunguje.

Podobně i matka z rodiny č. 7 si vybavuje, že její rodiče byli velmi zaměstnaní, a že se jí proto hodně věnovala její babička. Také ona nechce tento model opakovat.

... moje máma pracovala od mejch šesti měsíců, co jsem se narodila... ale já jsem nechodila do jeslí, starala se o mě babička... a v době, kdy jsem byla doma, moje máma pracovala jako zubařka, takže byla poměrně vytížená... žádný kroužky tenkrát nepamatuju, asi to nebylo v módě... ale snažím se to dneska dělat jinak... chceme jim dát to nejlepší...

Matka z rodiny č. 5 jako důvod neúčasti svého syna $v$ mateřské škole uvedla, že nebyl očkován. V dalším rozhovoru však přiznává, že by netrvala na pravidelné docházce svých dětí do mateřské školy ani v případě, kdyby problém s přijetím neočkovaných nenastal. Vzpomíná si, že v dětství navštěvovala své prarodiče jen velmi málo a prakticky vždy pouze o prázdninách, což ji mrzelo. Má velmi dobré vztahy se svými rodiči i rodiči manžela a chce, aby její děti byly s nimi ve větším kontaktu, než kdysi ona byla se svými prarodiči.

... většinou jo, je ten management toho žití takovej složitější... není to tak hezky nalajnovaný jako s tou školkou... ale jako zase si myslím, že si ty menší děti víc užijou rodinu, třeba já jsem neměla vůbec možnost jako menší dítě být třeba s babičkou a dědou, jenom třeba o prázdninách za odměnu, že jo [se smíchem]... a třeba vím, že Alena i Vlasta, protože máme výbornou, to je moje tchyně vlastně, že mají babičku.

Matka v rodině č. 3 nevzpomíná na své dětství moc pozitivně:

... že takový to naše vyrůstání na těch sídlištích, co si pamatuju já jako dítě, bylo naprosto nudný... nenaplňující a sedávali jsme po lavičkách a... nebylo to tolik naplňující, jako mají třeba děti v...

Chce synovi dopřát, po čem vždy toužila, tedy naučit se dobře lyžovat, hrát tenis a získat kvalitní jazykovou výbavu.

Z rozhovorů s matkou z rodiny č. 4 vyplývá, že v paměti má vzpomínky na svou školní docházku, ze kterých vystupuje především jistá uniformita, kolektivnost a pevný řád tehdejší doby. Pro své dvě dcery se proto snaží hledat jiné cesty ve výchově a vzdělání, preferuje jejich spokojenost, radost ze hry a z práce, dobrovolnost, volbu činností a vnitřní motivaci. Nechce, aby zažily to, čím prošla ona v osmdesátých letech 20. století. 
... já právě to vidím na sobě, že já jsem vyrůstala v té... klasické škole, kdy to hodně bylo daný tím... výkonem, jo, a celkově to ohodnocení a přijetí ze strany jako veřejnosti... tak moje přijetí bylo jen skrze ten výkon, a to včetně těch rodičů, jo, který samozřejmě to zase dělali jen kvůli tomu, že oni tak byli vedení, jo... moji rodiče vlastně... moje mamka... který ted'ka je šedesát osm let, že jo, a v té době toho... komunismu docela drsného... a všichni jim ř́kali, jo, to je třeba ty děti takhle vést, tak oni nás takhle vedli, že jo, a neviděli v tom nic špatného... člověk jim to nevyčítá, že spousta věcí... mi vlastně docházelo až s tím příchodem těch mých dětí...

\subsection{Nedůvěra v zajištění všestranného rozvoje dítěte mateřskou školou}

Sledovaní rodiče vnímají velmi vážně svoji odpovědnost za rozvoj a vzdělávání svého dítěte již $v$ předškolním věku. Mateřským školám však vesměs vzdělávací roli nepřisuzují. Pokud dítě nedochází do mateřské školy, získají tím volný čas, který systematicky využívají pro cílený a všestranný rozvoj dítěte.

Jednou z možností, jak se k odpovědnosti za vzdělávání dítěte postavit, je učení dítěte přímo rodičem, čehož jsme byli svědky při návštěvě rodiny č. 1. Matka klade velký důraz na vzdělání a zejména na výuku cizích jazyků. Syna předškoláka učí anglicky, starší syn s ní chodí společně na kroužek ruštiny. Doma mají plno CD s anglickými písničkami a hrami. Děti si rády prohlížejí různé encyklopedie, na počítači plní připravené didaktické úkoly a hrají dětské hry. Kromě vzdělávacích činností a aktivit doma matka dbá i na volnočasové aktivity chlapců, vodí je na bojový sport budo.

$\checkmark$ rodině č. 3 je prioritou sport a všestranný rozvoj syna. Kromě lyžování a tenisu, které jsou na prvním místě, chce matka, aby si syn vyzkoušel a zvládl co nejvíce aktivit a sportů s tím, že časem si vybere, v čem bude úspěšný.

... jdeme do bazénu nebo na brusle... hodně jsme to loňskou zimu spojovali s tou němčinou, že po němčině jsme šli na brusle na hodinku a pak už jsme vlastně přijeli domů.

Chlapec se svým dědou-trenérem tráví většinu zimy v Rakousku na lyžařských tréninkových kempech. Nicméně i doma se matka snaží, aby se rozvíjel a připravoval na vstup do Ž̌.

... my spolu doma počítáme, učíme se písmenka, hrajeme šachy, což chci, aby uměl takovýhle hry, kdy musí zapojovat trošičku mozek.

Pobyt $v$ Rakousku je využíván $\mathrm{k}$ podpoře výuky německého jazyka, kterou matka také považuje za významnou.

$\checkmark$ rodině č. 6 rovněž dominuje sport. Matka chce, aby se synové rozvíjeli po sportovní stránce, ale výběr sportu nechává na nich. Obě děti nyní chodí trénovat fotbal, ale vystřídaly i jiné sporty.

Matka v rodině č. 4 se snaží, aby se dcery věnovaly tomu, co je baví a co vidí pro sebe jako smysluplné. Klade důraz na emoce, na fyzickou odolnost, ale nikoli na dril 
a povinnost. Jako podstatný vnímá prožitek, radost ze hry, nikoli činnost zaměřovanou pouze na výkon a kognitivní oblast.

... že Zuzka ještě chodí na různé kroužky... a třeba jeden z nich je tady v čajovně, je to takový výtvarný ateliér, který trvá, myslím, hodinu a půl, a to vidím úplně, tak jak ji to baví, tak ta koncentrace tam je, opravdu je ochotná hodinu a půl se koncentrovat, soustředit na to, že něco tvoří... něco tam vzniká, je to takový hezký, protože to vidí, ten výsledek.

Matka vychází z toho, že $\mathrm{k}$ všestrannému rozvoji dítěte jsou nezbytné svoboda a možnost experimentovat. Snaží se jim dát dostatek volnosti a chce, aby si vše vyzkoušely.

... taky doma, to je neuvěřitelné... vůbec se jako nebojí... tuhle ř́kala, tak já si ušiju kabelku, a ted'kon vezme látku a fakt jako si to ustřihne, navlíkne jehlu, sešije, jo, takový jako by... jak třeba i tam v té školce mají možnost a ten dar toho rozdělávat ten oheň, tak [se smíchem], tak mi třeba taky máme doma kamna, tak prostě zatopí v kamnech, jo, anebo i tak, tak jo, tak já to uvařím... tak jako fakt taková odvaha do všeho se pustit a velká neustále inspirace, jo, ona i hodně, vidím, jak i tvoří, pořád něco jako modeluje a maluje a střihá a spojuje.

Toto směřování vede i k tomu, že je preferována alternativní škola s prvky lesní nebo Montessori pedagogiky. Matka se přidala k podobně smýšlejícím rodinám, které založily lesní školku, do které docházela její mladší dcera.

... a pak teda $v$ ten okamžik byla tady další iniciativa, vlastně vznikla waldorfská iniciativa a jejím cílem bylo založení lesního klubu, vlastně takový klasický lesní školky, a ta je v kopcích v Roupově, to je mezi... a... v těch nejvyšších kopcích, fakt jako nádherný prostředí, úplně nádherný lesy, louky... prostě takovej ráj, jo.

Pro rodinu č. 5 je velice důležitá mezigenerační výměna zkušeností, kladou důraz na rodinné vztahy a pouta s prarodiči dětí. Nejde jim jen o pomoc s obstaráním a pohlídáním dětí při pracovním vytižení, ale stanovili si pravidelný režim, kdy děti určité dny v týdnu tráví u prarodičů, kteři se jim rádi věnují:

... takže tam máme ještě druhé výchovné prostředí u babičky... kde je babička, děda a teda ještě svobodný švagr... co že se potom asi taky $\mathrm{k}$ tomu dostaneme, vlastně pro Vlastu počítač... Vlastu hodně baví počítání, že si s dědou hodně povídaj' o číslech, co to vlastně je... písmenka taky, ale čísla jsou zábavnější, to může jako... má nějakej vjem asi jako lepší a s dědou hráli karty, takže čísla a to... to ho hrozně baví.

\subsection{Předčasná scholarizace}

Pro dotazované rodiče je typické, že teprve základní školu považují za první institucionální stupeň vzdělávací dráhy jejich dětí. Mateřskou školu pokládají především za zařízení, které „hlídá“ děti, když rodiče chodí do práce. Povinnost institucionálně se vzdělávat v dřivější době, než odpovídá základní škole, se jim jeví jako předčasná: 
... to si ř́kám, at' si to rodiče dělaj', jak chtěj'... (rodina č. 1)... ta škola je povinná a ta mateřská škola... jako já nevím, no, mně to přijde takový už moc organizovaný, zbytečně moc diktujou, nevím, fakt mi to jako přijde zbytečný, ta školka... (rodina č. 6)

Pozitivním aspektem docházky do mateřské školy je pro některé rodiny možnost adaptace dětí na kolektiv, která zvyšuje šanci lépe zahájit školní docházku. Matkám, které jsou v domácnosti (rodina č. 1, 3, 6 a 7), by nic nebránilo mít své dítě stále doma, ale v rozhovorech přiznávají, že je nutné, aby si jejich dítě zvyklo na kolektiv vrstevníků. Alespoň částečná docházka je tedy u nich snahou začlenit dítě do kolektivu. Potřebnost adaptace na kolektiv si uvědomují i ostatní rodiny. Nevolí však $\mathrm{k}$ dosažení tohoto cíle vždy oficiální cestu mateřské školy, ale i alternativní možnosti, jako je účast ve spíše neformálních institucích (rodiny č. 4, 5) nebo kroužcích, prípadně setkávání se s podobnými rodinami přátel (rodina č. 7).

Pouze okrajově matky zmiňují, že mateřská škola může podpořit rovněž kognitivní rozvoj dítěte, ale zároveň dodávají, že jej mohou stejně dobře, ne-li lépe, podpořit samy. Rodina č. 1 v prvním rozhovoru zmiňuje, že je např́klad možné využívat au-pair nebo chůvy. Rodiny vesměs deklarují, že aktivní a zajímající se rodiče své dítě dokážou na vstup do základní školy adekvátně připravit i bez „pomoci“ státní instituce:

... a znám typy rodičů, který tu školku nenavštěvujou a právě jejich děti jsou excelentně připraveny, takže, asi by to nebylo něco, na čem bych bazírovala. To dávat těm rodičům za povinnost, no... (rodina č. 7)

Tazatelka: ... takže to, že nechodí pravidelně do školky, neznamená, že by měl nějak strach ze školy nebo tak.

Matka: ... ne, to ne, on je fakt tak společenskej, že je mu úplně jedno, kam půjde... ne vůbec... nemá žádný sociální... vůbec... (rodina č. 6)

Důsledkem tohoto př́stupu u sledovaných rodin je, že nevidí potřebu pravidelné docházky do mateřské školy a není jim tak jasný smysl zavedení povinné docházky v posledním ročníku mateřské školy. Povinnost chodit do mateřské školy proto rodiny berou v kontextu jejich chápání začátku vzdělávací dráhy dítěte jako omezování jejich svobody a zasahování státu do věcí, které mu nepř́sluší:

... no, já v tom vidím prostě jenom snahu toho systému jako absolutní kontroly, to je jakoby všechno, co k tomu dokážu rríct, já jsem z toho byla jako dost smutná... (rodina č. 5)

\section{Diskuse}

Zavedení povinné docházky $v$ posledním ročníku mateřské školy bude určitě představovat výrazný zásah do fungování života mnoha rodin. Zajímaly nás především rodiny, které nejsou sociálně znevýhodněné a kterým se z tohoto důvodu nevěnuje tolik pozornosti v pedagogickém výzkumu ani vzdělávací politice. Cílem našeho výzkumu pak bylo hledat motivaci těchto rodin, proč své děti neposílají do mateřské školy, 
nebo posílají, ale jen nepravidelně. Naše šetření identifikovalo některé podobné faktory, které můžeme nalézt $v$ zahraničních studiích zabývajících se hledáním príičin, jež ovlivňují volbu péče o dítě (např. v úvodu zmiňované Johansen, Leibowitz, \& Waite, 1996; Early \& Burchinal, 2001; Kim \& Fram, 2009).

Sledované rodiny lze charakterizovat jako přehnaně ochranitelské, velmi akcentují potřeby dítěte. Tendence maximálně vyhovět momentálnímu prání dětí vede často u sledovaných rodin až $v$ jejich neschopnost nastavit pevný řád $v$ životě dětí. Lze poté pozorovat snahu těchto rodin o prodloužení „bezstarostného“ dětství, která se projevuje i tím, že rodiny ve velké miře uvažují o odkladu povinné školní docházky. K odkladu školní docházky v polovině případů mezi sledovanými rodinami skutečně došlo.

Dalším rysem zkoumaných rodin je velká aktivita směrem $\mathrm{k}$ vzdělávacím potřebám svých dětí. Zajímají se o problematiku vzdělávání mnohem více než předcházející generace a často i hledají alternativní způsoby a formy vzdělávání. Své děti cíleně vzdělávají samy doma a hledají pro ně i rozmanité a bohaté volnočasové aktivity, do jejichž zajištění investují mnoho vlastní energie i financí. Za velmi důležitou v této souvislosti považujeme skutečnost, že tito rodiče nevnímají mateřskou školu jako organizaci, která bude jejich děti efektivně vzdělávat a rozvíjet. Její přínos pro rozvoj svých dětí spatřují primárně v tom, že jim zajistí společnost jiných dětí důležitou $\mathrm{k}$ získání sociálních dovedností. Tím, že netrvají na docházce svých dětí do mateřské školy, je subjektivně neochuzují, ale právě naopak: volného času využívají k tomu, aby dětem zajistili hodnotnější a rozmanitější vzdělávací a rozvíjející aktivity. Je samožrejmě otázka, do jaké míry je hodnocení významu mateřské školy těmito rodiči správné, ale je zřejmé, že v těchto př́padech bude obtížné vymáhat docházku do mateřské školy s odůvodněním, že je důležitá pro rozvoj dítěte a správný start jeho vzdělávací dráhy.

S cílem zajistit svým dětem optimální rozvoj tito rodiče aktivně přistupují k volbě základní i mateřské školy. Tato aktivita vede někdy i př́mo $\mathrm{k}$ spoluzakládání alternativních mateřských a základních škol, resp. k přímé účasti na jejich chodu. Je však nutné podotknout, že tyto aktivity nemusí vždy souviset $s$ nesouhlasem rodičů $s$ veřejným školstvím, ale příčinou mưže být i nedostatek míst $v 1$. tř́dách a nástup silných populačních ročníků do ZŠ. Tomuto jevu je však v každém př́padě třeba věnovat významnou pozornost. Je i zajímavým zjištěním, že alternativní mateřské školy nenavštěvují jen ty děti, jejichž rodiče hledají optimální vzdělávací př́ležitosti, ale i děti, které by za jiných podmínek běžně nastoupily do veřejné mateřské školy. Přirozeným důvodem je lepší dostupnost alternativní školy, nicméně existují i jiné důvody. Se zajímavým př́ipadem jsme se setkali při našem šetření, kdy nepřijetí do mateřské školy bylo z důvodu neprovedeného očkování (viz rodina č. 5 výše). Rodiče se rozhodli své dítě neočkovat, přestože $z$ oficiálního lékařského pohledu očkováno být mohlo. Toto pravidlo týkající se očkování však neplatí pro školní docházku v základní škole a při zápisech do 1 . tríd se tato skutečnost o budoucím prvňáčkovi většinou nezjišt'uje. Zákon pouze zmiňuje, že se tito žáci nemohou účastnit pobytových akcí školy a trrídy. Je jistě dobré, že tomuto problému již tvưrci vzdělávací politiky začali věnovat potřebnou pozornost. 
Pokud bychom se snažili celé rozhovory analyzovat vzhledem $\mathrm{k}$ uváděným důvodům neúčasti, můžeme konstatovat, že jsou často reakcí rodičů (především pak matek) na jejich dětství. Sledovaní rodiče docházeli do mateřské, resp. základní školy především $v$ osmdesátých letech minulého století. Z rozhovorů jednoznačně vyplynulo, že $v$ jejich paměti zůstávají vzpomínky na nesvobodu, určitou uniformitu a kolektivnost. Změněná společenská situace vedla $\mathrm{k}$ rozvoji svobody, došlo $\mathrm{k}$ uvolnění pevného řádu a vzniklo mnoho nových možností i v oblasti vzdělávání. To jistě ovlivnilo a ovlivňuje ty rodiny, pro které je důležitá svoboda, jistá volnost režimu nebo na druhé straně aktivní způsob života. Není jistě náhoda, že takto orientované rodiny byly identifikovány právě $v$ našem šetření.

Současně je tato skupina rodin často logicky citlivá na mnohdy pro ně nejasné a dle nich omezující rozhodnutí státu ohledně povinné docházky v posledním ročníku mateřské školy. Tato nedůvěra vůči tomuto rozhodnutí a neochota $k$ povinné pravidelné docházce pramení také z faktu, že dotazovaní rodiče berou za začátek povinné vzdělávací dráhy až základní školu. Povinnost institucionálně se vzdělávat $v$ dřivějším věku hodnotí jako předčasnou.

Je jistě proto rozumné pečlivě zvažovat formy této povinnosti a nastavení vhodných podmínek pro její plnění, v této souvislosti se jeví vhodná alternativa domácího předškolního vzdělávání. Zároveň se však ukazuje, že velkou pozornost je užitečné věnovat motivaci a vysvětlování důležitosti předškolního vzdělávání. Z řady výzkumů sice vyplývá jednoznačně pozitivní dopad předškolního vzdělávání na vzdělávací dráhu žáka a tvưrci vzdělávacích politik jsou si toho vědomi a akcentují tento fakt. $\mathrm{Na}$ druhé straně $\mathrm{i} z$ našeho šetření vyplývá, že některé rodiny si této vzdělávací stránky mateřských škol nejsou vědomy a plánované zavedení povinné docházky do mateřských škol pak chápou, bohužel, jen jako násilné zasahování státu do života rodin a omezování „bezstarostné“ etapy života dítěte bez zjevného důvodu.

\section{Závěr}

Pokud nás zajímá problematika rodin dětí, které se neúčastní pravidelné preprimární př́ínravy $v$ posledním roce před nástupem do základní školy, nelze $v$ tomto ohledu věnovat pozornost jen začleňování dětí ze sociálně slabých rodin, jakkoli je to důležité. Náš výzkum byl proto koncipován tak, aby primárně nesledoval sociálně a ekonomicky znevýhodněné rodiny, ale zaměřil se na rodiny „běžné“. Smysluplnost tohoto kroku dokladuje již dřive zmíněné naše kvantitativní šetření v Libereckém kraji a další výzkum (Hůle et al., 2015), z kterých vyplývá, že mezi rodinami, jejichž děti nenavštěvují mateřskou školu, je mnohem početnější skupina rodin bez socioekonomického znevýhodnění.

Zavedení povinné docházky v posledním ročníku mateřské školy bude určitě představovat výrazný zásah do fungování života těchto rodin. Povinná docházka však ovlivní výrazně i chod rodin s dětmi, které navštěvují mateřskou školu nepravidelně. Smyslem našeho výzkumu bylo seznámit se s důvody nedocházky dětí v těchto rodi- 
nách a zjistit názory rodičů dětí na výchovu a vzdělávání v předškolním období a na úlohu předškolního vzdělávání.

Naše kvalitativní sonda ukazuje i na několika případech, že tato populace sice není homogenní, ale že u ní lze identifikovat některé společné charakteristiky, které se u rodin s výrazně nižším socioekonomickým statusem nevyskytují (GAC, 2010; Nová škola, 2011). Jedním z těchto rysů je výrazný ochranitelský výchovný styl sledovaných rodin. Především matky vycházejí dětem vstříc v plnění jejich přání, chrání je před nepř́ijemnostmi, snaží se jim zajištovat pohodlí, nelpí příliš na dodržování povinností a pravidel. Tento přístup pak přirozeně vede $\mathrm{k}$ minimálně nepravidelné docházce do mateřské školy.

Na druhé straně u zkoumaných rodin lze pozorovat odpovědnost za vzdělávání svých dětí a aktivitu $v$ tomto směru. $V$ tomto kontextu za velmi důležité považujeme zjištění, že mateřská škola není brána rodiči jako organizace, která děti efektivně vzdělává a rozvíjí. Důvodem nedocházky do mateřské školy je získání volného času, který je možné využít pro rozmanitější vzdělávací a rozvíjející aktivity dětí podle představ rodičů. Z provedené analýzy vystupuje ještě další aspekt chování a jednání rodin. Lze jej jednoduše charakterizovat jako reakci matek na jejich dětství. Jejich konkrétní zážitky se sice ve zkoumaných případech obvykle liší, ale vždy chtějí své děti ušetřit vlastním negativním zkušenostem, což ve svém důsledku je důvodem nedostatečné docházky dětí do mateřské školy.

Sledované rodiny za začátek povinné vzdělávací dráhy svých dětí považují až základní školu. Mateřskou školu vnímají jen jako zařízení, které pomáhá rodičům, když se nemohou věnovat svým dětem, protože pracují. Chápou sice, že je nutné, aby si jejich dítě zvyklo na kolektiv vrstevníků před vstupem do základní školy, ale podle jejich názoru roli sociální adaptace dětí nemusí převzít jen mateřská škola. Vesměs tak nevidí smysl docházet do mateřské školy pravidelně, natož pak povinně.

Předloženou studii považujeme pouze za dílčí první krok možného výzkumu v naznačeném směru, nebot' především počet dotazovaných rodin byl v kontextu velikosti cílové populace přiliš malý. Naše studie tak nemohla postihnout všechny aspekty studované problematiky. Další její omezení spatřujeme v tom, že je vázána pouze na malou oblast ČR, a nemusí tak ukázat možná jiná chování a postoje rodin, které mohou být determinovány prostorově jinými regiony. V neposlední řadě limitujícím faktorem aktuálnosti našeho sdělení je i aktivita tvưrců vzdělávací politiky, která přinesla v posledním období - a stále přináší - řadu nových legislativních předpisů, opatření a postupů.

\section{Poděkování}

Děkujeme editorům tohoto čísla a zejména recenzentům za cenné připomínky, které výrazně pomohly zkvalitnit náš text. 


\section{Literatura}

Barnett, W. S. (1995). Long-term effects of early childhood programs on cognitive and school outcomes. The Future of Children, 5(3), 25-50. Dostupné z https://www.princeton.edu /futureofchildren/publications/docs/05_03_01.pdf

Berlinski, S., Galiani, S., \& Gertler, P. (2006). The effect of pre-primary education on primary school performance. Ann Arbor: William Davidson Institute at the University of Michigan. Dostupné z http://ideas.repec.org/p/wdi/papers/2006-838.html\#provider

Dvořák, D., Starý, K., Chvál, M., Urbánek, P., \& Walterová, E. (2010). Česká základní škola. Víceprípadová studie. Praha: UK, Karolinum.

EACEA P9 Eurydice. (2009). Vzdělávání a péče v raném dětství v Evropě: překonávání sociálních a kulturních nerovností. Brusel: Výkonná agentura pro vzdělávání, kulturu a audiovizuální oblast. Dostupné z http://eacea.ec.europa.eu/education/eurydice/documents /thematic_reports/098CS.pdf

Early, D. M., \& Burchinal, M. R. (2001). Early childhood care: Relations with family characteristics and preferred care characteristics. Early Childhood Research Quarterly, 16(4), 475-497.

Evropský parlament. (2013). Kvalita předškolního vzdělávání a péče. Brusel: EU. Dostupné z http://www.europarl.europa.eu/studies

GAC. (2010). Vzdělanostní dráhy a vzdělanostní šance romských žákyň a žáků základních škol $\checkmark$ okolí sociálně vyloučených romských lokalit. Praha: MŠMT.

Gambaro, L., Stewart, K., \& Waldfogel, J. (2014). Format an equal start? Providing quality early education and care for disadvantaged children. Bristol: Policy Press.

GreatSchools Staff. (2016). 10 good reasons your child should attend preschool. Great! Schools. Dostupné z https://www.greatschools.org/gk/articles/why-preschool/

Greger, D., Simonová, J., \& Straková, J. (Ed.). (2015). Spravedlivý start? Nerovné šance $\checkmark$ předškolním vzdělávání a při přechodu na základní školu. Praha: PedF UK.

Hůle, D., Kaiserová, I., Kabelová, K., Mertl, J., Moravec, Š., Svobodová, K., \& Št’astná, A. (2015). Zavedení povinného posledního roku předškolního vzdělávání před zahájením školní docházky (Studie proveditelnosti). Plzeň: Tedy a ted' a Demografické informační centrum.

Johansen, A. S., Leibowitz, A., \& Waite, L. J. (1996). The importance of child-care characteristics to choice of care. Journal of Marriage and Family, 58(3), 759-772.

Kim, J., \& Fram, M. S. (2009). Profiles of choice: Parents' patterns of priority in child care decision-making. Early Childhood Research Quarterly, 24(1), 77-91.

Kleňhová, M. (2013). České školství v mezinárodním srovnání: Česká republika v indikátorech OECD, resp. v indikátorech publikace Education at a Glance 2013. Praha: MŠMT.

Komise evropských společenství. (2006). Účinnost a spravedlnost v evropských systémech vzdělávání a odborné př́pravy (Sdělení komise KOM 481 v konečném znění). Brusel: EU. Dostupné z http://eur-lex.europa.eu/legal-content/CS/TXT/PDF/?uri=CELEX:52006DC 0481 \&from $=$ CS

Leix, A. E. (2006). Transkripce audionahrávek v kontextu etickém, metodologickém a technickém (Disertační práce). Brno: FSS MU.

Melhuish, E. C. (2004). A literature review of the impact of early years provision upon young children, with emphasis given to children from disadvantaged backgrounds (Report to the controller and auditor general). London: National Audit Office. Dostupné z http://www .nao.org.uk/publications/ nao_reports /03-04/268_literaturereview.pdf

Miller, E., \& Almon, J. (2009). Crisis in the kindergarten: Why children need to play in school. College Park, MD: Alliance for Childhood.

MŠMT. (2014). Strategie vzdělávací politiky České republiky do roku 2020. Dostupné z http: // www.msmt.cz/uploads/Strategie_2020_web.pdf

MŠMT. (2016). Rámcový vzdělávací program pro předškolní vzdělávání. Dostupné z http:// www.msmt.cz/file/38795/ 
Nová škola. (2011). Infant matter: Raná péče a předškolní výchova, vyhodnocení focus groups (Závěrečná zpráva). Praha: Nová škola.

OECD. (2014). Does pre-primary education reach those who need it most? PISA in Focus, 40(6).

O'Hehir, A. (2010). Why our kids don't go to kindergarten. Salon. Dostupné z https://www .salon.com/2010/03/15/home_school_3/

Patton, M. Q. (1990). Qualitative evaluation and research methods. Newberry Park, CA: Sage.

Rühm, C., \& Waldfogel, J. (2012). Long-term effects of early childhood care and education. Nordic Economic Policy Review, 1(6149), 23-51.

Schütz, G. (2009). Does the quality of pre-primary education pay off in secondary school? An international comparison using PISA 2003, Ifo working paper no. 68. Munich: Ifo Institute for Economic Research at the University of Munich.

Syslová, Z., \& Najvarová, V. (2012). Předškolní vzdělávání v České republice pohledem pedagogického výzkumu. Pedagogická orientace, 22(4), 490-515.

Šmelová, E. (2005). Předškolní vzdělávání očima rodičovské veřejnosti. Pedagogická orientace, 15(1), 52-58.

Yoshikawa, H. (1995). Long-term effects of early childhood programs on social outcomes and delinquency. The Future of Children, 5(3), 51-75.

Zákon č. 178/2016 Sb., kterým se mění zákon č. 561/2004 Sb., o předškolním, základním, středním, vyšším odborném a jiném vzdělávání (školský zákon), ve znění pozdějších předpisů, a zákon č. 200/1990 Sb., o přestupcích, ve znění pozdějších předpisů. Dostupné z https: / /www.psp.cz/sqw/sbirka.sqw?cz=178\&r=2016

Mgr. Helena Picková, Katedra pedagogiky a psychologie Technická univerzita v Liberci, Fakulta přirodovědně-humanitní a pedagogická Studentská 2, 46117 Liberec helena.pickova@tul.cz

Ústav výzkumu a rozvoje vzdělávání Univerzita Karlova, Pedagogická fakulta Myslíkova 7, 11000 Praha 1 